\title{
ВИКОРИСТАННЯ ІНФОРМАЦІЙНИХ ТЕХНОЛОГІЙ ДЛЯ ВІДНОВЛЕННЯ ПАЦІЄНТІВ ПІСЛЯ ЕНДОПРОТЕЗУВАННЯ КУЛЬШОВОГО СУГЛОБА
}

\author{
О. О. Глиняна, Ю. А. Попадюха \\ Національний технічний університет України \\ «Київський політехнічний інститут»
}

\begin{abstract}
В роботі розглянуто застосування інформаційних технологій для відновлення після тотального ендопротезування кульшового суглоба. Розроблено алгоритм прийняття рішення реабілітологом під час процедури на технічних засобах. Відмічена висока ефективність застосування технічних засобів для відновлення пацієнтів.

Ключові слова: технічні засоби, ендопротезування, відновлення, кульшовий суглоб.

\section{ИСПОЛЬЗОВАНИЕ ИНФОРМАЦИОННЫХ ТЕХНОЛОГИЙ ДЛЯ ВОССТАНОВЛЕНИЯ ПАЦИЕНТОВ ПОСЛЕ ТОТАЛЬНОГО ЭНДОПРОТЕЗИРОВАНИЯ ТАЗОБЕДРЕННОГО СУСТАВА}

\author{
О. А. Глиняная, Ю. А. Попадюха \\ Национальный технический университет Украины \\ «Киевский политехнический институт»
}

\begin{abstract}
В работе рассмотрено использование информационных технологий для восстановления после тотального эндопротезирования тазобедренного сустава. Разработан алгоритм принятия решения реабилитологом во время процедуры на технических средствах. Отмечена высокая эффективность использования технических средств для восстановления пациента.
\end{abstract}

Ключевые слова: технические средства, эндопротезирование, восстановление, тазобедренный сустав.

\section{USAGE OF INFORMATION TECHNOLOGIES FOR PATIENTS' RECOVERY AFTER HIP REPLACEMENT}

\author{
O. O. Hlyniana, Yu. A. Popadiuha \\ National Technical University of Ukraine \\ "Kyiv Polytechnic Institute"
}

\begin{abstract}
The usage of information technologies for recovery after total hip replacement was considered. The algorithm of making a decision by a rehabilitologist during the procedure with mechanical facilities was developed. High effectiveness of mechanical facilities usage for patients' recovery was observed.
\end{abstract}

Key words: mechanical facilities, endoprosthesis, recovery, hip joint.

Вступ. Інформаційні технології в медицині займають важливе місце. Інформаційні технології значно допомагають лікарю-реабілітологу отримувати, зберігати, передавати певну необхідну інформацію та керувати станом пацієнта. Організм пацієнта включається в складну комплексну систему. Якщо першу частину такої системи складають підсистеми, що функціонують патологічно, або цілісний організм пацієнта, то до іiї другої частини можна віднести численну та різнорідну сукупність засобів, що дають змогу виявити патологію, діагностувати іiі, визначити розвиток та керувати процесом відновлення пацієнта. В основу покладено якісну відмінність другої підсистеми, що разом з пацієнтом формує комплексну систему: лікар, реабілітолог, технічні засоби, навколишнє середовище.

Вирішуючи завдання діагностики, фізичної реабілітації (ФР), прогнозування та керування пацієнтом, лікар і реабілітолог працюють спільно з сучасними засобами комп'ютерної техніки. Вони дають мож-

(C) О. О. Глиняна, Ю. А. Попадюха, 2011 
ливість широко використовувати математичне оброблення інформації і створюють умови для ефективного розв'язання різноманітних завдань [4, 5].

Це привело до появи цілого класу нових складних систем, у тому числі й біотехнічних систем (БТС). Складність цих систем визначається не новим об'єктом дослідження та керування, що має якісно нову складність, а складністю взаємодії людини з технічними засобами, у тому числі комп'ютерними, що функціонують всередині системи, при вирішенні поставлених завдань. При цьому дії людини та технічних засобів об'єднуються не жорстким, не фіксованим алгоритмом взаємодії, а ефективність розв'язання задач визначається їх спільною інтелектуальною потужністю. Щодо режиму взаємодії, то він визначається активним діалогом між пацієнтом, лікарем, реабілітологом та комплексом технічних засобів для розроблення адекватного, не відомого раніше загального алгоритму функціонування. Сучасний рівень технології отримання знань дав змогу усвідомити необхідність фіксації алгоритмів дослідження.

Підкреслимо, що основою інформаційних технологій $\epsilon$ експериментальні дослідження, котрі дають можливість одержати дані - первинний інформаційний масив, що є першим і необхідним кроком у пізнанні об'єкта, який досліджується. Наступним кроком є усвідомлення (упорядкування) цих даних - попередня обробка, з метою «спрощення» даних для розуміння отриманої інформації. Для одержання нових знань інформації про пацієнта, який досліджується, треба усвідомити цю інформацію, тобто надати їй змістовність. Звідси випливає ідея інформаційної технології: усвідомлення тріади «дані-інформація-знання» як необхідного методу отримання нового знання.

Отже, інформаційні технології - це систематизація подання знань, створення логічних та обчислювальних засобів для вирішення завдань встановлення закономірностей з первинних інформаційних масивів, побудова ефективно реалізованих теорій та реабілітаційних інформаційних систем. Інформаційні технології виступають як інструмент комп'ютерного аналізу даних і знань високого рівня $[4,5]$.

Активною об'єднувальною ланкою інформаційноструктурної моделі БТС керування функціональним станом пацієнта є реабілітолог. Роль реабілітолога у такій БТС зводиться до наступного: отримання інформації з бази даних, лікаря (встановлення діагнозу) в результаті усвідомлення ним суб'єктивної інформації на підставі лікарського досвіду. Відповідно до інформаційно-структурної моделі, роль лікаря полягає в отриманні інформації, а реабілітолога - у виконанні.
Під банком методів і засобів розуміють алгоритм стандартизації, класифікації, уніфікації, первинної статистичної обробки інформаційних масивів. Така структура БТС допомагає керувати станом пацієнта та коригувати ймовірні відхилення від норми за допомогою отриманих даних лікарем. Верифікований банк існуючих відхилень, допомагає лікарю та реабілітологу зреагувати на проблему та ефективно iї вирішити.

Інформація, що надходить до реабілітолога, повинна надаватись у зручній для сприйняття і достатній для побудови концептуальної моделі ситуації формі, на базі якої коригується алгоритм, або режим дії біологічного елемента (цілісного організму) - ланки БТС. Застосування інформаційно-структурної моделі дає можливість підвищити ефективність діагностики, контролю та своєчасного реагування на відхилення у стані здоров'я пацієнта, що дозволить зменшити періоди перебування у стаціонарі та фізичної реабілітації $[2,4]$.

Визначення особливостей реабілітації пацієнтів, як біологічних елементів БТС, необхідне для вирішення багатьох завдань, зокрема вибору профілактичних i відновних заходів, контролю функціонального стану (ФС) і психо-фізіологічного стану (ПФС) у реальному часі, підтримання життєдіяльності організму.

За допомогою біотелеметричних систем (БТМС) визначають і оцінюють фізіологічні параметри (наприклад, ЧСС, артеріальний тиск, температуру, частоту дихання тощо), отримують інформацію про стан пацієнта. Для підвищення ефективності реабілітаційних заходів необхідно мати комплекс засобів різних типів, а саме: систему моніторингу з контролем ФС пацієнта та керування їі діями, сучасні технічні засоби (Т3) тощо.

Новітні методи та засоби відіграють велике значення в ефективній післяопераційній реабілітації для забезпечення комплексного відновлення. При цьому важлива роль відводиться інформаційним технологіям, зокрема у відновленні стану пацієнта під час проведення занять на Т3.

Метою дослідження була оцінка використання інформаційних технологій для відновлення пацієнтів після ендопротезування кульшового суглоба (КС) i розробка алгоритму прийняття рішень реабілітологом під час процедури на Т3 (рис. 1).

Матеріал і методи дослідження. Авторами проаналізовано базу даних пацієнтів, методи і засоби діагностики та реабілітації. Особлива увага приділялась контролю проведених відновних заходів реабілітологом. Моніторинг діяльності, контроль стану пацієнта, керування діями здійснюється складовими БТС, зв'язаними між собою у загальному контурі керування. 


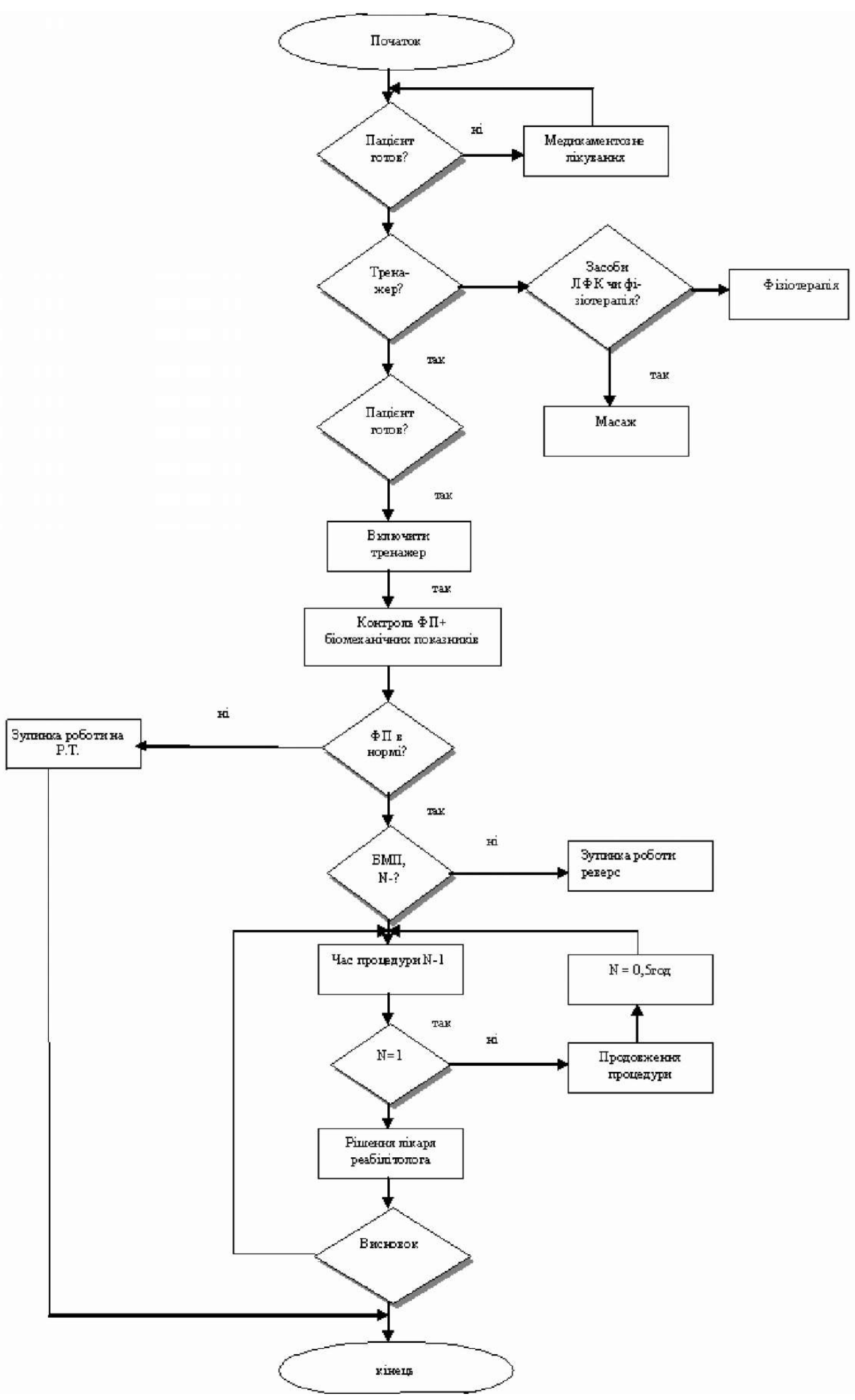

Puc. 1. Алгоритм прийняття рішень реабілітологом під час процедури на ТЗ. 
Для відновлення пацієнтів після тотального ендопротезування кульшового суглоба застосовували апарати для пасивного безперервного відновлення рухливості (CPM Lower Limb L4, CPM 480E, 520 CPM) нижньої кінцівки [3, 1, 6, 7].

Обрано 42 хворих (28 жінок і 14 чоловіків), яким було проведено тотальне ендопротезування КС, і які перебували у ортопедо-травматологічному відділенні Київської обласної клінічної лікарні № 1. Пацієнтів поділено на 2 групи: 1 -21 хворий (17 осіб віком 56-64 роки та 4 особи віком 65-72 роки), 2-21 хворий (16 осіб віком 56-64 роки та 5 осіб віком 65-72 роки).

Обстеження проводились в період до (12 \pm 2$)$ днів в стаціонарі та через 3, 6, 9, 12 місяців після ендопротезування за найбільш розповсюдженою уніфікованою 100 - бальною шкалою оцінки функції КС, що запропонована W. H. Harris [1]. Шкала вміщує оцінку таких показників: біль (50 балів), функцію КС (24 бали), амплітуду руху в КС (14 балів), осьову деформацію кінцівки (5 балів), м'язову силу (7 балів).

Друга група хворих займалася за звичайною програмою, яка включала лікувальну фізичну культуру. Перша група пацієнтів займалася на реабілітаційному тренажері CPM Lower Limb L4, що призначений для лікування та відновлення рухливості в КС. Засіб виконує широкий діапазон рухів на згинання в ділянці: КС: від $4^{\circ}$ до $100^{\circ}$; колінного суглоба: від - $10^{\circ}$ до $135^{\circ}$. Засіб також регулюється по розміру кожного пацієнта. Переваги для використання даної моделі стабільна кутова швидкість, яка попереджає адгезії та контрактури. Апарат мінімізує будь-які зміщення і забезпечує мінімальне навантаження на суглоб, забезпечує його синхронну розробку [3].

Алгоритм дії реабілітолога під час проведення процедури на Т3 (рис. 1) дає можливість послідовно виконувати дії, контролювати стан пацієнта та керувати його станом.

Послідовне проведення процедури дає можливість покращити біомеханічні показники КС та уникнути ускладнень. Всі показники контролює «лікар» - «реабілітолог» - «пацієнт», у разі їх відхилення процедуру припиняють або зменшують час процедури. Окрім функціональних (ФП) показників реабілітолог звертає увагу на біомеханічні показники (БМП).

У разі відхилення кута згинання КС реабілітолог приймає рішення припинити проведення процедури, якщо така ситуація виникає під час заняття на тренажері, настає реверс, одна з головних безпечних функцій апарату для пасивної розробки КС. Функція реверсу забезпечує безпечне заняття на тренажері і в разі виникнення сильного болю, м'язового напруження негайно повертає кінцівки у вихідне положення та припиняє тренування. Пацієнт сам може припинити заняття на тренажері та зупинити роботу ТЗ в разі виникнення дискомфорту та болю. Під час процедури на апаратах для пасивної розробки можна вимірювати ЧП, АТ, температуру за допомогою датчиків цифрового монітора і в разі їх відхилень припинити тренування.

Результати й обговорення. Через 14 днів інтенсивного застосування апаратів для пасивної розробки нижньої кінцівки ми отримали результати, які представлені на рисунках 2 та 3. Через 12 місяців нами

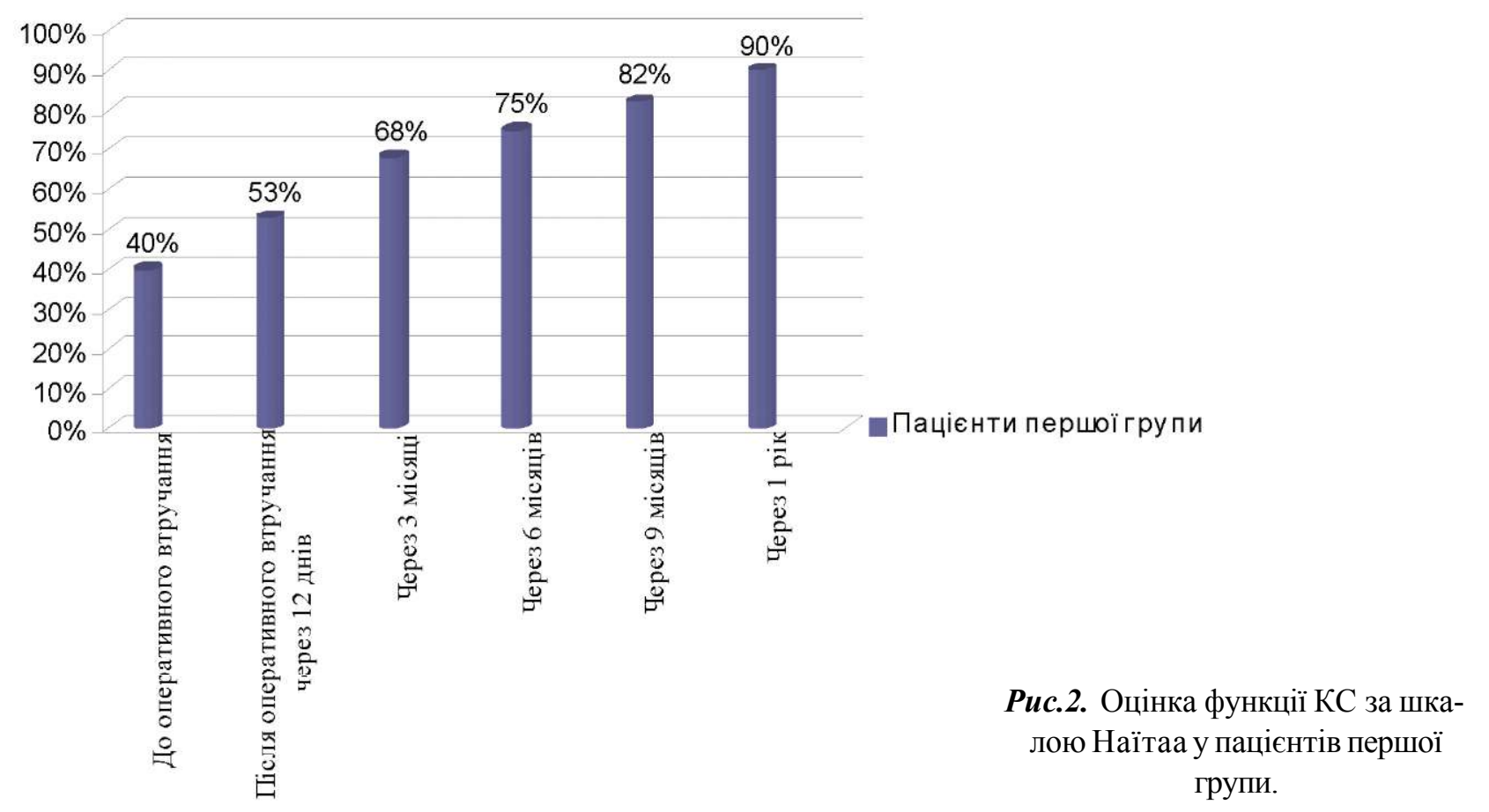




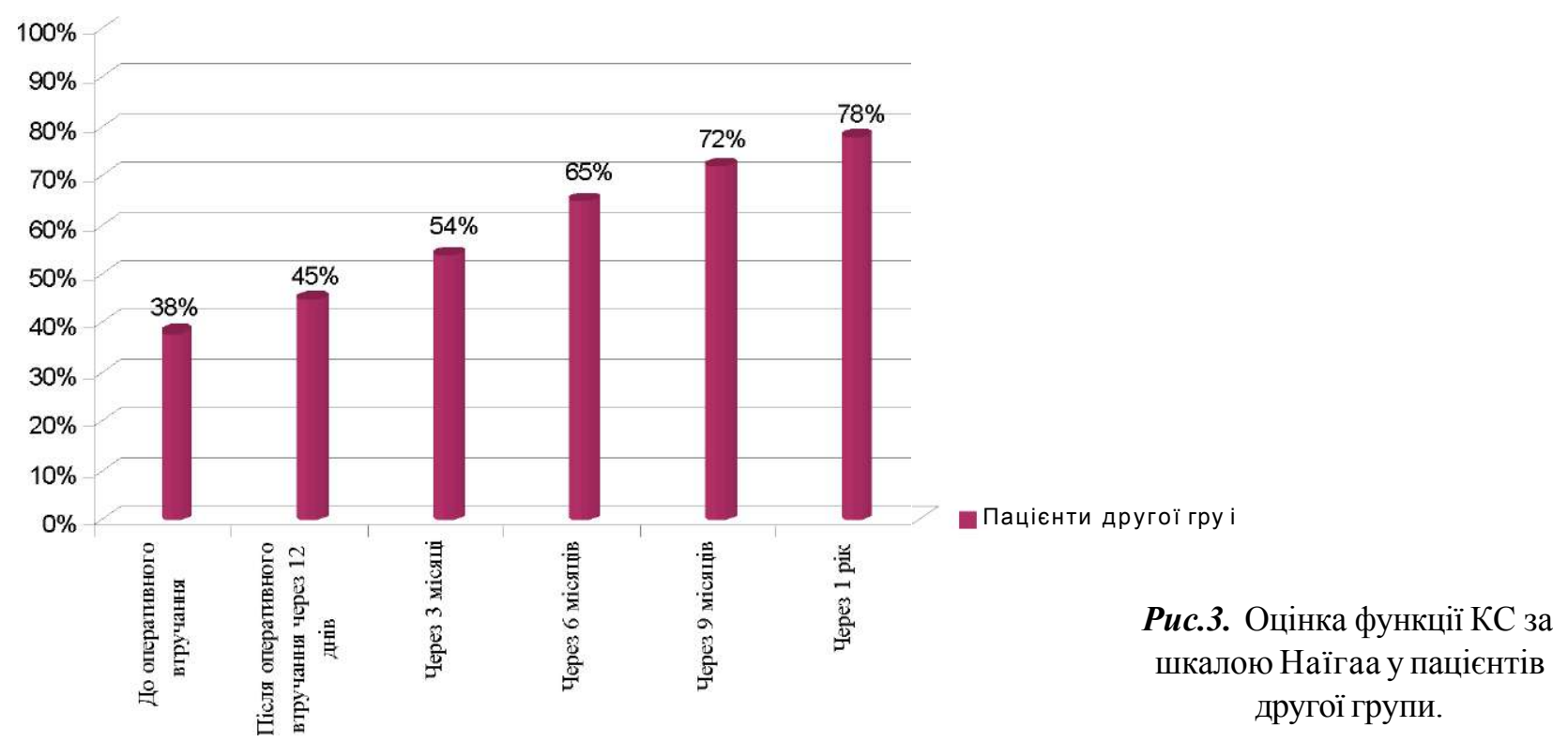

були тримані результати за шкалою Наїгаа, з яких зроблено висновок, що застосування Т3 значно покращило стан пацієнтів першої групи, i, особливо, їх біомеханічні показники. В другій групі були відмічені значно гірші показники.

Висновки. Розроблено алгоритм дій реабілітолога під час проведення занять на Т3, проведена оцінка використання інформаційних технологій для відновлення пацієнтів після ендопротезування КС за допомогою шкали Наїгаа. Використання апаратів для пасивної розробки КС в першій групі дало змогу отримати через 12 місяців реабілітаційних заходів 90 балів за шкалою Наїгаа; у другій групі - 78 балів. Застосування ТЗ у першій групі значно покращило біомеханічні показники, в результаті пацієнти отримали на 12 балів більше, а це свідчить про ефективність застосування наведеного засобу відновлення.

\section{Лiтература}

1. Анкин Л. Н. Практика остеосинтеза и эндопротезирования / Л. Н. Анкин, Н. Л. Анкин. - К., 1994. - 304 с.

2. Гриценко В. І. Інформаційні технології в біології та медицині / В. І. Гриценко, А. Б. Котова, М. І. Вовк [та ін.]. - К. : Наукова думка, 2007. - С. 291-293.

3. Довгань В. И. Механотерапия / В. И. Довгань, И. Б. Темкин. - М. : Медицина, 1981. -127 с.

4. Минцер О. П. Биологическая и медицинская кибернети- ка. Справочник / О. П. Минцер, В. Н. Молотков, Б. Н. Угаров - К. : Наукова думка, 1986. - 376 с.

5. Сокольский В. С. Информатика медицины / В. С. Сокольский. - М. : Познавательная книга плюс, 2001. - 704 с.

6. CRM Elogic Elbow E3. Инструкция по эксплатации. OrthoRehab. - $18 \mathrm{c}$.

7. Режим доступу: http://www.rusmedserv.com/orthopaedics/ hoffa.htm. 